\title{
The Impact of Job Satisfaction and Job Dissatisfaction on Herzberg Theory: A Case Study of Meezan Bank Limited and National Bank Limited
}

\author{
Sumra Haleem Shaikh \\ PhD Research Scholar \\ University of Sindh, Jamshoro \\ Pakistan \\ Haseeb Shaikh \\ Engineer, Civil department \\ Mehran Universityof Engineering and technology \\ Riyadh Saudia Arabia \\ SumairShaikh \\ Engineer, Mechanical department \\ Quaid e Awam University of Engineering \\ Science and technology \\ Nawabshah, Pakistan and Maintenance Manager Javedan Corporation Limited
}

\begin{abstract}
The purpose of this study is to scrutinize the impact of job satisfaction and job dissatisfaction on employees' performance in Meezan bank limited (MBL) and National bank limited (NBL). Seven point Likert scale is used for survey purpose. Reliability test, Pearson correlation, Analysis Of Variance (ANOVA), t testand multiple regression techniques are used for data analysis. The results have shown that job satisfaction is positively effects on employees' performance and job dissatisfaction is negatively effects on employees' performance. Job satisfaction factors boosts the staff performance of Meezan Bank Limited and National Bank Limited that ultimately increase reputation of their organizations as well as help in economic growth.
\end{abstract}

Keywords: Job satisfaction, Job dissatisfaction, Employee performance, Motivators, Hygiene factors, Herzberg theory

\section{Introduction}

MBL stands for Meezan Bank Limited and NBL stands for National Bank Limited. Both banks are profitable and national banking services. In market economy, banking services are really playing a significant role. This study will contribute a major role for motivating members of staff by keeping in consideration the motivators and hygiene factors. According to Martin, G. R. (1991), job satisfaction may seem to be similar as motivators or content factors and job dissatisfaction may appear in form of hygiene or context factors. These both factors are highly applied in management of organizations. Job dissatisfaction is opposite of job satisfaction at that situation employees feels unhappy and frustration at their jobs (Raziq \& Maulabakhsh, 2015).Job satisfaction is defined as feeling of an individual about their job in different perspectives (Aziri, 2011). Job satisfaction is playing a vital role in performance of organization by providing their employees the best services (Robbins \& Judge, 2003).

According to Raziq \& Maulabakhsh (2015),motivators of Herzberg two-factor theory as advancement, achievement, recognition, work itself, growth and job satisfaction are important factors, which positively affect the banking systems where as job dissatisfaction create the negative impact on banking systems. Motivated employees are key ingredients, which gives the expected results as well as boost the performance and productivity. Job satisfaction is a crucial way for achievement of goals in every organization. Good banking policy in form of rewards will enhance the motivation of employees in competitive environment (Edna, 2010).

\section{Literature Review}

Research by Hyun (2009) was capable to represent similarity of motivation and hygiene factors to job satisfaction and job dissatisfaction respectively, by means of questionnaire methodology who was enable to developed the relationship of motivation-hygiene factors matched with intrinsic-extrinsic job satisfaction. Employees are internally motivated if they control their results regarding performance of job for achieving the desired goals(Martin, G. R., 1991). 
Dahlqvist and Matsson (2013) argued that the main factors, which influence the employee performance, are rewards. Rewards cause satisfaction with both intrinsically and extrinsically and make the employees' work more productive. Emekaet al., (2015) asserted that performance depends on many factors like job security, employees' satisfaction, training and development, compensation, appraisals, positive feedback, intrinsic and extrinsic rewards. Through motivation, employees do their best work with strenuous at certain circumstances and face the greasy challenges easily.

According to Dahlqvist and Matsson (2013), the job satisfaction and job dissatisfaction influence the employee performance. Job satisfaction is increased by intrinsic motivational factors such as advancement, achievement, work itself, recognition and growth (Herzberg et al., 1959; Herzberg et al., 1966). Factors, which decrease job dissatisfaction, are company policy, good working conditions, job security, supervision, relationship with peers and money (Herzberg et al., 1959; Herzberg et al., 1966).Job satisfaction increase the employee's satisfaction and job dissatisfaction decrease the employee's satisfaction that ultimately give results in poor performance.

The elements, which create job dissatisfaction are poor policies, insecurity, poor relations with boss and employees, inflexible working condition and low salaries (Okpara, 2004). The clashes between lower and upper staff create negative impact on their organization (Arnetz, 1999; Lane, Esser, Holte, \& McCusker, 2010; Raziq \& Maulabakhsh, 2015). Job dissatisfaction occur when employees feel anger, depression and resentment in their job (Matthews, 2011). Job dissatisfaction is process where employees are not comfortable at their workplace (May, 1978). Dissatisfaction happens when employees do not want to do work because of unhappiness and discontent in work (Locke, 1976). According to Herzberg et al., (1966), hygiene factors eliminate job dissatisfaction but absence of hygiene factors cause dissatisfaction.

Herzberg (1959) discussed motivation from two different perspectives of job satisfaction as motivators and job dissatisfaction as hygiene factors (Stello, 2012). Job satisfaction is process a person feels good and relaxation regarding their tasks and performance of their job (Herzberg, 1959). Job satisfaction is state of emotions positively arise from an individual job's appreciation (Locke, 1976). Job satisfaction comprises certain spaces, for example, high pay, advancement opportunities, security of jobs, high recognition and interesting work (Nguyen, Taylor, \& Bradley, 2003).

Previous studies mostly found that job satisfaction is concerned with pay, work-related easiness, company policy, accomplishment, self-awareness, association with others and flexible working conditions (Shikdar \& Das, 2003; Wright \& Cropanzano, 1997). For enhancing the productivity, organizations ought to pay cautious consideration and time to workplace as well as social interactions among employees that are essential and significant for job satisfaction (Chandrasekar, 2011).

According to Herzberg, the dissatisfaction is one partial of assignment of two-factor theory. The additional partial is improved by satisfaction in the organization but this is only possible when managers apply motivating factors (Yuosef, 2000). Two-factor theory believed that individuals are motivated by lower-level needs (extrinsic or hygiene factors) due to elimination of dissatisfaction for better performance. Top stage of requirements (intrinsic or motivation factors) should be given, for motivating and improving employee's performance (Robbins, 2009; Ramlall, 2004).

Present study summarized that motivators work at higher occupational level and hygiene work at lower occupational level. This study placed value both of factors, hence it is concluded that intrinsic and extrinsic rewards placed a great importance on workers performance. Workers will dissatisfied if these rewards, not given to them.

\section{Scope of The Study}

Existing thesis will provide benefits to many areas relating to hospitals, educational institutions and organizations. Present study will provide bundle of knowledge for coming researchers. Current study will contribute their major part in academic's professionals to identify supportive relationship amongst job satisfaction and job dissatisfaction with employees' performances.

\section{Research Objectives}

Current study considers subsequent objectives:

I.To estimate the influence of job satisfaction factors on performance of employees.

II.To estimate the influence of job dissatisfaction factors on performance of employees.

\section{Methodology}

In current thesis, research methodology is very important portion for analyzation of data from MBL and NBL banks. The data for this study were collected through questionnaires. For this purpose, 680 copies of questionnaire were banking industry. Reliability test was conducted through SPSS version 20.0. Pearson correlation, $t$ test, ANOVA and multiple regressions techniques were used for analysis of data. In this regard, Jarque Bera test was employed. 
On basis of Jarque Bera, all variables used in multiple regression were normally distributed. Convienence non probability technique and random sampling techniques were used in present study. The selected area was Hyderabad, Sindh.

\section{Results and Discussions}

\subsection{Demographic Profile For Combined MBL And NBL}

Gender category represented that there were $100 \%$ male in combined MBL and NBL. Age category in MBL and NBL combined exhibited that highest ratio of 54.5\% employees from age group of 41-50 years, second highest ratio of $37.3 \%$ employees from age group of 51-60 years, $25.7 \%$ employees from age group of 31-40 years while $8.9 \%$ employees from age group of 21-30 years in MBL and NBL combined. In MBL and NBL combined, work experience category displayed that $58.7 \%$ employees had more than 15 years experience, $19.2 \%$ employees had 6 to 10 years experience, $15.3 \%$ employees had 1 to 5 years experiene while $12.2 \%$ employees had 11 to 15 years experience.Job status of MBL and NBL demonstrated that $96.0 \%$ employees were employed on permanent basis while $4.0 \%$ were working on contractual basis.Education category in MBL and NBL revealed that $52.1 \%$ employees were bachelors, $39.9 \%$ employees had done Master, $17.9 \%$ employees belonged to college while $1.9 \%$ employees belonged to high school and other professionals.Last category is marital status which represented that $97.9 \%$ emplyees were married and $2.1 \%$ employees were ummarried.

\subsection{Statistical Analysis}

The value of mean of motivators and hygiene factors are greater than 5 which is close to the degree of agree level of statement. The cronbach alpha of motivators and hygiene factors is statistically good and excellent. In MBL, all intrinsic factors have small but definite relationship with job satisfaction. But in NBL, work itself and recognition have moderate relationship while growth, advancement and achievement have small but definite relationship with job satisfaction. Whereas hygiene variables of both banks (MBL and NBL) effects negatively to job dissatisfaction. There is significant relationship between motivators with job satisfaction and no affiliationamongst hygiene variables with job dissatisfaction.

According to table 1, in MBL, the coefficient of determination is mentioned by $\mathrm{R}$ square is 0.552 and Adjusted $\mathrm{R}$ square is .551. This model have explained the variance which described that five independent variables have explained $55.2 \%$ of variation in job satisfaction. By measuring through ANOVA, the F-statistic is 1041.174, which show high strength of model. As a result, the model has given a good description of association among explained and unexplained factors. Whereas in NBL, the coefficient of determination is mentioned by R square is 0.581 and Adjusted R square is .580. This model have explained the variance which described that five independent variables have explained $58.1 \%$ of variation in job satisfaction. By measuring through ANOVA, the F-statistic is 1201.075, which show high strength of model. As a result, the model has given a good description of association among explained and unexplained factors. From the Coefficient's table, all intrinsic variables have positive significant association with job satisfaction.

According to table 2, in MBL, the coefficient of determination is mentioned by $\mathrm{R}$ square is 0.530 and Adjusted $\mathrm{R}$ square is .530. This model have explained the variance which described that six independent variables have explained $53.0 \%$ of variation in job dissatisfaction. By measuring through ANOVA, the F-statistic is 1810.618, which show high strength of model. As a result, the model has given a good description of association among explained and unexplained factors. From the Coefficient's table, all extrinsic variables have negative significant association with job dissatisfaction. Whereas in NBL, The coefficient of determination is mentioned by R square is 0.518 and Adjusted R square is .518. This model have explained the variance which described that six independent variables have explained $51.8 \%$ of variation in job dissatisfaction. By measuring through ANOVA, the F-statistic is 1770.838, which show high strength of model. As a result, the model has given a good description of association among explained and unexplained factors. From the Coefficient's table, all extrinsic variables have negative significant association with job dissatisfaction.

\section{Conclusion}

High job satisfaction allied with greater competence, success, efficiency and productivity. Supervisors of banking industries have encouraging their employees to bring any concern about trust during their session as well as protect the interest of all employees in industries. This study suggested that there is need for improving employee levels by means of providing responsibility for their work $t$ employees for creating their interest in the work and facilitating them with training for boosts the performance of organization through applying motivators and hygiene factors. Job satisfaction increases the productivity of company, profits, reduce cost and turnover of employees. 
Job satisfaction improves the working conditions, provide a chance of advancement, increase the individual personality, create positive relations with peers and increase the quality of work with performance in banking industries. Organizations should build the teams through which employees can discuss their issues face to face that ultimately increase the level of satisfaction among employees.

\section{References}

Arnetz, B. (1999). Staff perception of the impact of health care transformation on quality of care. International Journal for Quality in Health Care, 11, 345-351.10.1093/intqhc/11.4.345

Aziri, B. (2011). Job satisfaction: A literature review. Management Research and Practice,3, 77-86.

Chandrasekar, K. (2011). Workplace environment and its impact organizational performance in public sector organizations. International Journal of Enterprise Computing and Business Systems, 1(1), 1-19

Dahlqvist, A., \& Matsson, A. (2013). The impact of extrinsic and intrinsic rewards on employees' motivation: A case study of an insurance company

Edna Naa Amerley Okorley. (2010). University of Cape Coast Factors Influencing the Motivation of Bank Staff in the Cape Coast Metropolis Factors Influencing the Motivation of Bank Staff in the Cape Coast Metropolis.

Emeka, N., Amaka, O., \& Ejim, E. P. (2015). The Effect of Employee Motivation on Organizational Performance of Selected Manufacturing Firms in Enugu State. World Journal of Management and Behavioral Studies, 3(1), 18. https://doi.org/10.5829/idosi.wjmbs.2015.3.1.1314

Herzberg, F. H., Mausner, B., \& Snyderman, B. S. (1959). The motivation to work. John Wiley and Sons

Hyun, S. (2009). Reexamination if Herzberg's two factor theory of motivation in the Korean Arcurrent foodservice operation.

Jurkiewicz, C. L., Massey, T. K and Brown, R. G. (1998). Motivation in Public and Private Organizations: A Comparative Study. Public Productivity \& Management Review, 21(3), 230-250

Lane, K., Esser, J., Holte, B., \&McCusker, M. M. (2010). A study of nurse faculty job satisfaction in community colleges in Florida. Teaching and Learning in Nursing,5, 16-26.10.1016/j.teln.2009.05.001

Locke, E. (1976). The nature and causes of job satisfaction. Handbook of Industrial and Organisational Psychology, Chapter 30.

Maksuc, F. (2016). Employee motivation and satisfaction: The case of Clinical Centre University of Sarajevo

Martin, G. R. (1991). Job factors contributing to the job satisfaction and job dissatisfaction of primary principals in one Ministry of Education district in Western Australia. Retrieved from http://ro.ecu.edu.au/theses/1124

May, B. R. (1978). A Study of Herzberg's Motivation-Hygiene Theory of Job Satisfaction as It Relates to Academic Personnel in Selected Small Liberal Arts Colleges

Nazir, A. N. (1998). Perceived Importance of Job Facets and Overall Job Satisfaction of Bank Employees. Indian Journal of Industrial Relations, 33(4), 479-496

Nguyen, A., Taylor, J., \& Bradley, S. (2003). Relative pay and job satisfaction: Some new evidence.MPRA, 1382. Retrieved from https://mpra.ub.uni-muenchen.de/1382/1/MPRA_paper_1382

Okpara, J. O. (2004). The impact of salary differential on managerial job satisfaction: A study of the gender gap and its implications for management education and practice in a developing economy. Journal of Business in Developing Nations, 8, 65-91.

Owusu, B. (2014). An assessment of job satisfaction and its effect on employees' performance: A case of mining companies in the [BIBIANI - ANHWIASO - BEKWAI DISTRICT] in the western region

Rahman, K.-U., Akhter, W., \& Khan, S. U. (2017). Factors affecting employee job satisfaction: A comparative study of conventional and Islamic insurance. Cogent Business \& Management, 4(1). https://doi.org/10.1080/23311975.2016.1273082

Ramlall, S. (2004). A Review of Employee Motivation Theories and their Implications for Employee Retention and their Implications for Employee Retention within Organisations. Journal of American Academy of Business, 5(1/2), 52-63. https://doi.org/10.1063/1.2053360

Raziq, A., \& Maulabakhsh, R. (2015). Impact of Working Environment on Job Satisfaction. Procedia Economics and Finance, 23, 717-725

Robbins, S. P., \& Judge, T. (2003). Essentials of organizational behavior. Upper Saddle River, NJ: Prentice Hall,7

Robbins, S. P. (2009). Organizational behavior. Social Psychology: Handbook of Basic Principles., 2nd Ed., 913-939. Retrieved http://ovidsp.ovid.com/ovidweb.cgi?T=JS\&PAGE=reference\&D=psyc5\&NEWS=N\&AN=2007-11239-040

Shikdar, A. A., \& Das, B. (2003). The relationship between worker satisfaction and productivity in a repetitive industrial task. Applied Ergonomics,34, 603-610 
Smerek, R. E and Peterson, M. (2007). Examining Herzberg's theory: Improving Job Satisfaction among NonAcademic Employees at a University. Research in Higher Education, 48 (2), 229-250

Stello, C. M. (2014). Herzberg's Two-Factor Theory of Job Satisfaction: An Integrative Literature Review. Herzberg's Two-Factor Theory of Job Satisfaction, 32. https://doi.org/10.7537/marslsj140517.03

Wright, T. A., \&Cropanzano, R. (1997). Well-being, satisfaction and job performance: another look at the happy/productive worker thesis. In Academy of Management Proceedings. 1, 364-368

Yousef, D. A. (2000). Organizational commitment and job satisfaction as predictors of attitudes toward organizational change in a non-western setting. Personnel Review, 29(5), 567-592.

https://doi.org/10.1108/00483480010296401

Table 1 Compare the job satisfaction of MBL and NBL

\begin{tabular}{|l|l|l|}
\hline Job satisfaction & MBL & NBL \\
\hline R square & 0.552 & 0.581 \\
\hline Adjusted R square & 0.551 & 0.580 \\
\hline F value & 1041.174 & 1201.075 \\
\hline P value & 0.000 & 0.000 \\
\hline
\end{tabular}

Table 2 Compare the job dissatisfaction of MBL and NBL

\begin{tabular}{|l|l|l|}
\hline Job dissatisfaction & MBL & NBL \\
\hline R square & 0.530 & 0.518 \\
\hline Adjusted R square & 0.530 & 0.518 \\
\hline F value & 1810.618 & 1770.838 \\
\hline P value & 0.000 & 0.000 \\
\hline
\end{tabular}

